\title{
Spider mites associated to soybean in Rio Grande do Sul, Brazil
}

\author{
Samuel Roggia ${ }^{(1)}$, Jerson Vanderlei Carús Guedes (2), Rejane Cristina Roppa Kuss ${ }^{(2)}$, \\ Jonas André Arnemann ${ }^{(2)}$ and Denise Návia(3)
}

\begin{abstract}
(1)Escola Superior de Agricultura Luiz de Queiroz, Departamento de Entomologia, Fitopatologia e Zoologia Agrícola, Caixa Postal 9, CEP 13418-900 Piracicaba, SP, Brazil. E-mail: sr_roggia@yahoo.com.br (2)Universidade Federal de Santa Maria, Centro de Ciências Rurais, Departamento de Defesa Fitossanitária, Avenida Roraima, no 1.000, Bairro Camobi, CEP 97105-900 Santa Maria, RS, Brazil. E-mail: jerson.guedes@smail.ufsm.br, rkuss2003@yahoo.com.br, jonasarnemann@yahoo.com.br (3)Embrapa Recursos Genéticos e Biotecnologia, Caixa Postal 02372, CEP 70770-900 Brasília, DF, Brazil. E-mail: navia@cenargen.embrapa.br
\end{abstract}

\begin{abstract}
The objective of this work was to study the occurrence and geographic distribution of phytophagous mites associated to soybean in Rio Grande do Sul, Brazil. Samplings were performed from January to May 2005 on genetically modified soybean (glyphosate-tolerant) crops, in 27 municipalities of six regions - Alto Vale do Uruguai, Campanha, Depressão Central, Planalto Médio, Missões and Serra do Sudeste. Five phytophagous mite species belonging to the family Tetranychidae-Mononychellus planki, Tetranychus desertorum, T. gigas, T. ludeni and T. urticae - occurred in 21, 12, 5, 3 and 14 municipalities, respectively. A map of Rio Grande do Sul with the geographic distribution of each species is presented, as well as an illustrated dichotomous key to help the identification of the spider mites found.
\end{abstract}

Index terms: Glycine max, Mononychellus planki, Tetranychus, glyphosate-tolerant soybean, taxonomy.

\section{Ácaros associados à soja no Estado do Rio Grande do Sul}

\begin{abstract}
Resumo - O objetivo deste trabalho foi estudar a ocorrência e a distribuição geográfica de ácaros fitófagos associados à soja, no Rio Grande do Sul. As amostragens foram realizadas de janeiro a maio de 2005, em lavouras de soja geneticamente modificada, tolerante ao glifosato, em 27 municípios de seis regiões - Alto Vale do Uruguai, Campanha, Depressão Central, Planalto Médio, Missões e Serra do Sudeste. Cinco espécies de ácaros fitófagos da família Tetranychidae - Mononychellus planki, Tetranychus desertorum, T. gigas, T. ludeni e T. urticae - ocorreram em 21, 12, 5, 3 e 14 municípios, respectivamente. Um mapa do Rio Grande do Sul é apresentado, com a distribuição geográfica das espécies nos locais de abrangência, bem como uma chave dicotômica ilustrada para auxiliar na identificação dos ácaros tetraniquídeos encontrados.
\end{abstract}

Termos para indexação: Glycine max, Mononychellus planki, Tetranychus, soja tolerante ao glifosato, taxonomia.

\section{Introduction}

The soybean and soy products is the most important soybean of Brazilian agribusiness export. In 2005 accounted for $21.7 \%$ of the total export revenue. In 2007 Brazilian soybean production was about 58.4 million Mg. The State of Rio Grande do Sul (RS) is the third largest Brazilian producer, with about 10 million $\mathrm{Mg}$, equivalent to $17 \%$ of the national production. In RS agribusiness export of 2005, the soybean complex was $9.8 \%$ of RS total export revenue (Brasil, 2006; FNP, 2007). In Brazil, more than $50 \%$ soybean fields are cultivated with genetically modified glyphosate-tolerant cultivars; in RS, the area cultivated with genetically modified soybean is almost 100\% (Gazeta Grupo de Comunicações, 2007).
Brazilian soybean cultivation is currently based on intensive use of agrochemicals for pest management, which results in a low-diversity environment and favors the development of phytophagous arthropod populations that could become pests. Recently, severe attacks of spider mites were observed on soybean in Brazil. Such occurrence has been considered abnormal and could be associated with alterations of the soybean production system. Among the factors probably favoring the occurrence of mites are the use of new soybean cultivars, with favorable nutritional and morphological composition (Elden, 1997; Ali, 1999; Abraham, 2000; Rita \& Lajos, 2001), increased use of glyphosate, which may reduce the biological diversity of the system and affect the arthropod population (Buckelew et al., 2000; Bitzer et al., 2002; Scursoni et al., 2006) and can be detrimental to 
entomopathogenic fungi (Morjan et al., 2002), pesticide use for pest management, which can influence, directly and indirectly, the spider mite population (Gerson \& Cohen, 1989; Trichilo \& Wilson, 1993; Grout et al., 1997; Childers \& About-Setta, 1999; Sato et al., 2001, 2002; James, 2003; Beers et al., 2005; Prischmann et al., 2005), and the occurrence of droughts (Flechtmann, 1972).

In soybean integrated pest management, the identification and knowledge of the distribution of pests is essential, since pests can have distinct characteristics: potential damage, susceptibility to predators and pathogens, adaptation to climate factors and soybean cultivation conditions, season of occurrence, location in the plant, distribution within the crop, and susceptibility to pesticides.

Most phytophagous mites associated to soybean throughout the world belong to the family Tetranychidae, with 24 species reported (Flechtmann, 1972; Bolland et al., 1998; Navia \& Flechtmann, 2004; Guedes et al., 2007). Among these, Tetranychus urticae Koch is the species with the largest host plant range, and occurs in all continents (Bolland et al., 1998). In Brazil, the spider mite species reported on soybean are: T. urticae, Mononychellus planki (McGregor), T. desertorum Banks, T. ludeni Zacher, and T. gigas Pritchard \& Baker (Flechtmann, 1972; Navia \& Flechtmann, 2004; Guedes et al., 2007). In addition, the Tarsonemidae Polyphagotarsonemus latus (Banks) is also reported on soybean (Guedes et al., 2007).

Recently, in RS, severe attacks of mites on soybean were observed. These attacks were caused by the species M. planki, T. desertorum, T. gigas, and P. latus (Guedes et al., 2007). This was the first report of T. desertorum on soybean in Brazil, and the first one of T. gigas on soybean in the world (Navia \& Flechtmann, 2004). Probably, these species already occurred on soybean in RS, at low population levels, or had been incorrectly identified. Species known on soybean in Brazil, like T. urticae and T. ludeni (Flechtmann, 1972), were not found in those works. These facts suggest a possible change of the species that attack soybean in RS, thus requiring a more comprehensive study.

The objective of this work was to study the occurrence and geographic distribution of spider mites on soybean in Rio Grande do Sul, Brazil. In addition, an illustrated dichotomous key was prepared, based on the species of Tetranychidae found in this work, in order to facilitate their identification.

\section{Materials and Methods}

Fifty-two mite-infested genetically modified soybean samples were collected from January to May 2005, from
27 municipalities of six physiographic regions of RS: Alto Vale do Uruguai (Caiçara and Nonoai), Campanha (Rosário do Sul and Vila Nova do Sul), Depressão Central (Alegrete, Cacequi, Candelária, Itaara, Jari, Júlio de Castilhos, Restinga Seca, Santa Maria, São Pedro do Sul, and Silveira Martins), Planalto Médio (Barra Funda, Campos Borges, Cruz Alta, Espumoso, Não-Me-Toque, Panambi, Selbach, and Victor Graeff), Missões (Condor) and Serra do Sudeste (Caçapava do Sul, Cachoeira do Sul, Formigueiro, and São Sepé). Each sample comprised between 30 and 50 leaflets infested with mites, collected at random within the crop and at different sites in the plant.

The mites were mounted on microscopy slides in Hoyer's medium, and identified under a phase-contrast optical microscope attached to a digital camera and a microcomputer. Images of the structures of taxonomic interest for the various species were obtained.

Taxonomic keys and descriptions by Pritchard \& Baker (1955) and a recent redescription of T. gigas (Navia \& Flechtmann, 2004) were used to identify the species. These references also served as a basis in the preparation of the taxonomic key for the species found. A species distribution map for RS mites was prepared with Cria/speciesLink/speciesMapper System (CRIA, 2002).

\section{Results and Discussion}

Five phytophagous mite species were found, all belonging to the Tetranychidae family $-M$. planki, T. desertorum, T. gigas, T. ludeni, and T. urticae. These species occurred in $21,12,5,3$ and 14 municipalities, respectively (Figure 1). The occurrence of these mites was observed both at the edge and inside the crops, either in patches or with wide distribution over the crop, occupying extensive areas. The two species found in the highest number of locations, $M$. planki and T. urticae, occurred in Alto Vale do Uruguai, Planalto Médio, Depressão Central, and Serra do Sudeste regions of RS; M. planki also occurred in Missões and Campanha.

During 2003/2004 cropping seasons, Guedes et al. (2007) found M. planki on soybean only in Depressão Central, while T. urticae was not found in any of the 11 samples collected. The occurrence of these mites on soybean in the 2004/2005 cropping season, presented here shows that the mites were more widespread than in previous seasons. This fact may be attributed to the wider range of this work or may be explained as caused by the continuous series of cropping seasons with droughts, a climatic condition that favors large populations of these mites. 
The specie $M$. planki is only known from the Americas, from the Florida, USA, to Argentina (Bolland et al., 1998). In this work, it was observed that the attack of $M$. planki in soybean caused chlorosis on both sides of the leaf, evolving to a grayish color, with leaves later showing an aged aspect.

Tetranychus urticae is the most important mite-pest species of soybean worldwide. In Brazil, this species was rarely reported on soybean by authors like Flechtmann (1972). In the present work it was observed that the attack of T. urticae causes an initial mottled appearance on the lower side of soybean leaves and yellowish regions on their upper side; leaves, then, become tanned, dried, and finally fall off. These attacks occurred in patches.

M. planki and T. urticae can be distinguished by their color. Both are predominantly green, but the second has two dorsal dark spots on the sides of the podosoma. M. planki does not spin webs, while webs are abundant in T. urticae colonies. M. planki is found both on lower

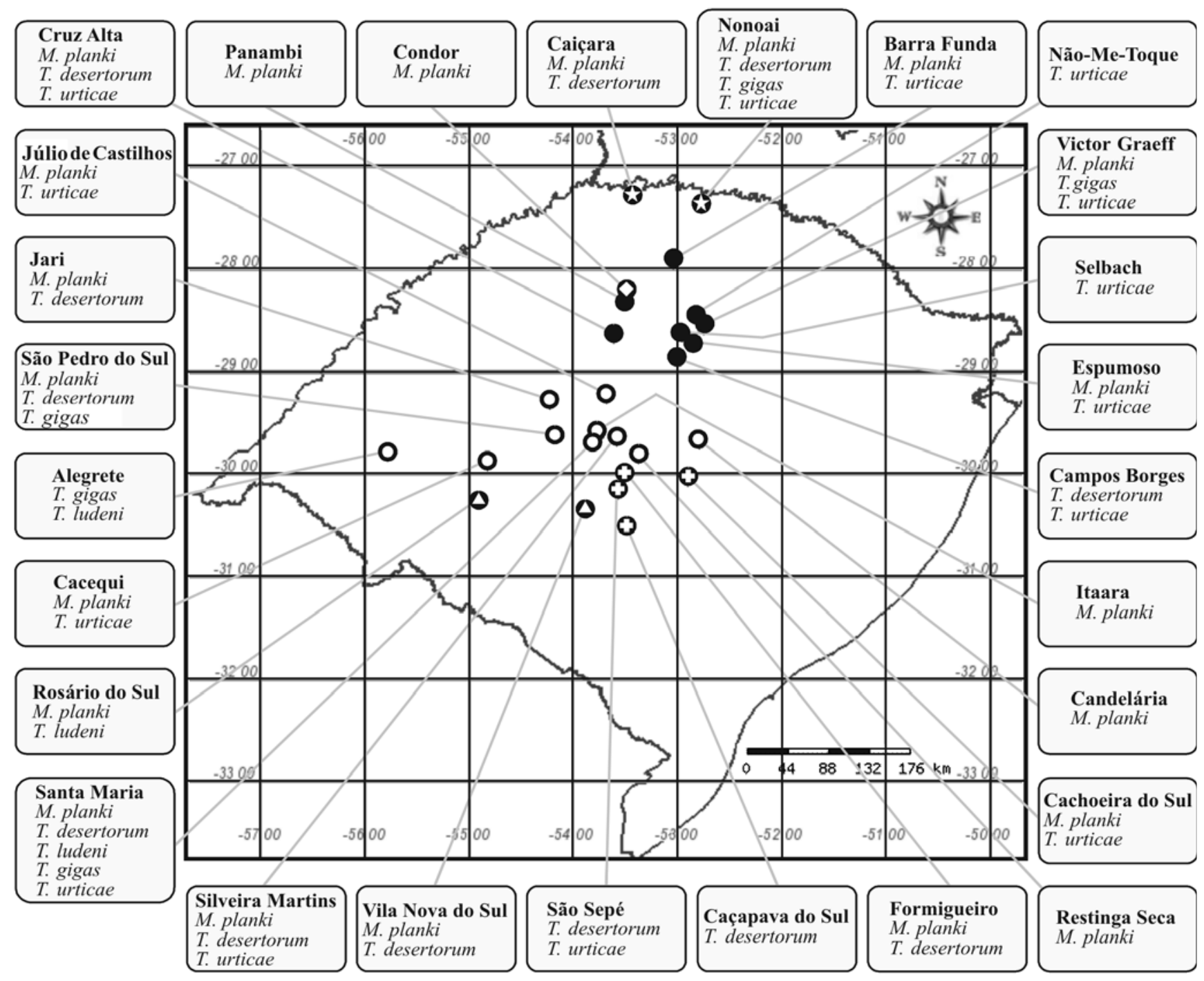

$\begin{array}{lll}\text { 放 Alto Vale do Uruguai } & \diamond \text { Missões } & \bigcirc \text { Planalto Médio } \\ \text { + Serra do Sudeste } & \Delta \text { Campanha } & \bigcirc \text { Depressão Central }\end{array}$

Figure 1. Distribution of soybean spider mite species (Tetranychidae) in Rio Grande do Sul, Brazil, during 2004/2005 cropping season. 
and upper surface of the leaf. Conversely, T. urticae and other Tetranychus species occur mainly on the lower surface of the soybean leaves.

T. ludeni was only found in samples from three municipalities of the Depressão Central and Campanha region. Although Guedes et al. (2007) did not find this species during 2002/2003 and 2003/2004 seasons, it had been reported previously on soybean by Flechtmann (1972). This mite species has wide distribution worldwide and attacks several plants, including soybean. In South America, it was reported in several countries, including Brazil, Argentina, Paraguay, Colombia, and Venezuela (Bolland et al., 1998).

The species T. desertorum was found in 19 samples from 12 municipalities, in Alto Vale do Uruguai, Planalto Médio, Depressão Central, Campanha, and Serra do Sudeste. Guedes et al. (2007) first reported T. desertorum on soybean in Brazil in Depressão Central and Serra do Sudeste. This cosmopolitan species has been observed on 193 hosts worldwide, including soybean (Pritchard \& Baker, 1955; Bolland et al., 1998; Guedes et al., 2007).

T. gigas was found in five samples from five municipalities in Alto Vale do Uruguai, Planalto Médio and Depressão Central. T. gigas was reported on soybean for the first time in the world in Depressão Central and Serra do Sudeste, during 2003/2004 cropping season (Navia \& Flechtmann, 2004).

So far, T. gigas has been reported from $25-32^{\circ} \mathrm{N}$ to 29-32 ${ }^{\circ} \mathrm{S}$ (Pritchard \& Baker, 1955; Navia \& Flechtmann, 2004). In this work, this species was found between 27 and $30^{\circ} \mathrm{S}$, near the north and south boundaries of the sampled area. Similar latitude ranges, although in different hemispheres, show similar climatic and biodiversity patterns. In this context, it is possible that T. gigas is adapted to typical and common ecological and climatic conditions of the regions where it has been found to date. Nevertheless, this species may not be restricted to these latitude ranges and more studies about its distribution in the country are required.

The red spider mites T. gigas, T. desertorum, and T. ludeni have similar general color and size, making it difficult to distinguish them under field conditions. The damage symptoms of these species on soybean, observed in this work, were similar to those produced by $T$. urticae, with leaf drop occurring under intense attack.

The broad mite, Polyphagotarsonemus latus, although already reported in RS on soybean in 2002/ 2003 in Canguçu (Guedes et al., 2007), was not found in this work, probably because of a drought occurred during the study period, which is detrimental to the broad mite (Flechtmann, 1967).
In the area studied, the occurrence of most mite species was widespread, and was not restricted to a particular region of the state, nor to narrow elevation ranges, except for T. ludeni, found only at Campanha and Depressão Central regions, at altitudes between 95 and $125 \mathrm{~m}$. However, it is possible that $T$. ludeni was attacking soybean in other regions of the State not covered in this work. In addition, the fact that it was present in a small number of samples could be related to a low population density. Consequently, it cannot be stated with confidence that this species has a restricted geographic distribution.

In addition, to these five spider mite species, identification at species level was not possible for some of the specimens found in some samples, due to the lack of males in the samples. These specimens were placed into two groups within the Tetranychus genus desertorum and urticae. The desertorum group refers to females with characteristics shared by the species T. desertorum, T. gigas, and T. ludeni. The urticae group refers to female individuals similar to $T$. urticae females. The unidentified specimens in the desertorum group were found in nine municipalities: Barra Funda, Cacequi, Cachoeira do Sul, Candelária, Condor, Itaara, Júlio de Castilhos, Panambi, and Restinga Seca. The unidentified specimens in the urticae group were found in Cachoeira do Sul and Não-Me-Toque.

Further studies on the attack of mites in soybean are required, to survey species, to investigate the factors which determine the occurrence of severe mite attacks to the crop, and to recommend management alternatives. Studies are also required on typical pattern of occurrence for each species, regarding plant site, colonization, distribution within the crop, visual characterization of the attack at plant and crop levels, damaging potential, host plants, and biological control agents associated to mite-pest populations. Mite surveys on soybean are also needed in other soybeanproducing regions of the state not encompassed by this work, as well as in other states where the occurrence of mite-pests has been observed in this crop.

The taxonomic key of soybean spider mites (Teranychidae), prepared to help in the identification of the species found in this survey, presents their most important morphological characteristics (Pritchard \& Baker, 1955; Navia \& Flechtmann, 2004):

1. FEMALE - with three pairs of $h$ setae (two pairs of para-anal setae); two pairs of duplex setae of tarsus I, approximate and in distal position; longitudinal striae between $e 1$ setae; dorsal setae base surrounded by reticulation: Mononychellus planki (McGregor 1950) (Figure $2 \mathrm{~A}, \mathrm{~F}, \mathrm{H}$ and $\mathrm{N}$ ). 
1'. FEMALE - with two pairs of $h$ setae (one pair of para-anal setae); two pairs of duplex setae of tarsus I, well-separated, a distal and other proximal, dividing the tarsus in three sub-equal parts; transverse dorsal striae

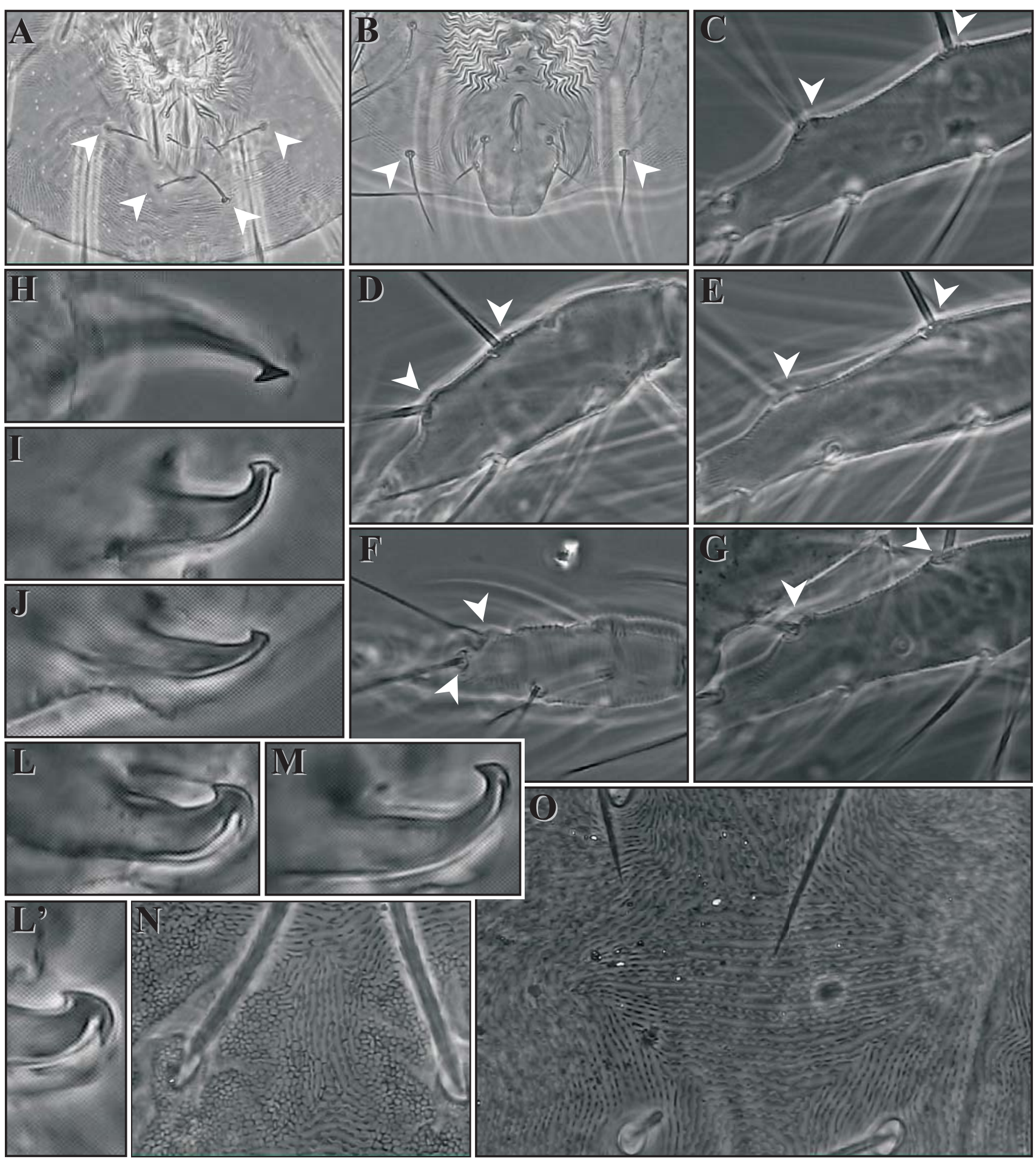

Figure 2. Morphological characteristics of soybean spider mites from Rio Grande do Sul, Brazil. A and B: female para anal setae position, Mononychellus planki and Tetranychus gigas, respectively; C, D, E, F, and G: duplex setae position, in female tarsus of T. ludeni, T. urticae, T. gigas, M. planki, and T. desertorum, respectively; H, I, J, L, and M: aedeagus of M. planki, T. urticae, T. ludeni, T. gigas, and T. desertorum, respectively; N: M. planki female, dorsal striae between $e 1$ setae and its basal reticulation; $O$ : diamond pattern of $T$. urticae female, among $e l$ and $f 1$ setae. 
among $e l$ and $f l$ setae, forming the diamond pattern; dorsal setae base not surrounded by reticulation (Figure $2 \mathrm{~B}, \mathrm{C}, \mathrm{D}, \mathrm{E}, \mathrm{G}$ and/or O): $\rightarrow 2$.

2. FEMALE - proximal duplex setae not in line with the proximal sensorial setae of tarsus I: Tetranychus urticae Koch 1836 (Figure 2 D, I and O).

2'. FEMALE - proximal duplex setae in line or approximately in line with the proximal sensorial setae of tarsus I (Figure $2 \mathrm{C}, \mathrm{E}$ or $\mathrm{G}$ ): $\rightarrow 3$.

3. MALE - the aedeagus body is narrow; aedeagus distal end (knob) with only one anterior pointed projection: Tetranychus ludeni Zacher 1913 (Figure 2 C and $\mathrm{J}$ ).

3'. MALE - the aedeagus body is narrow or broad; aedeagus distal end (knob) with two projections, the anterior projection is pointed and the posterior is downward curved (ventrally directed) (Figure $2 \mathrm{~L}$ or $\mathrm{M}): \rightarrow 4$.

4. MALE - the aedeagus body is broad; the aedeagus distal end (knob) is broad, about 1.5 time broader than T. desertorum, the posterior projection is well distinct: Tetranychus gigas Pritchard \& Baker 1955 (Figure 2 B, $\mathrm{E}$ and $\mathrm{L}$ ).

4'. MALE - the aedeagus body is narrow; aedeagus distal end (knob) less broad than T. gigas, the posterior projection is less distinct than T. gigas: Tetranychus desertorum Banks 1900 (Figure $2 \mathrm{G}$ and M).

\section{Conclusions}

1. The spider mite species which attacked soybean in 2004/2005 cropping season, in municipalities of Rio Grande do Sul State, are: Mononychellus planki, Tetranychus urticae, T. desertorum, T. gigas, and T. ludeni.

2. The spider mite species show a widespread distribution in the area comprised by this work, except for Tetranychus ludeni.

3. The spider mite species have a joint occurrence in the various municipalities studied in this work.

\section{Acknowledgements}

To Coordenação de Aperfeiçoamento de Pessoal de Nível Superior, for the financial support and master scholarship; to Alexandre Doneda, Geovane A. Zappe,
Juliano R. Farias, Juliano D. Martins, Martin B. Pasini, and Maurício Bigolin - students of Universidade Federal de Santa Maria -, to the Agronomists Diogo Brondani, Felipe Sulsbach, Heleno Maziero, Luis R. Jasniewcz, and Rafael P. Bortolotto and to Dr. Mauro T.B. da Silva Fundação Centro de Experimentação e Pesquisa -, for their help in the mite collections; to Marcella dos Reis and Glauce Gonçalves - Embrapa Recursos Genéticos e Biotecnologia -, for their help in the preparation of microscopy slides; to Dr. Carlos Holger Wenzel Flechtmann - Escola Superior de Agricutura Luiz de Queiroz -, for the manuscript reviewing.

\section{References}

ABRAHAM, R. Mite and thrips populations of soybean varieties of different ripening groups. Novenyvedelem, v.36, p.583-589, 2000.

ALI, N.A. Soybean leaf aging influencing the preference and nonpreference to Tetranychus urticae (Koch), with reference to certain cultivars. Assiut Journal of Agricultural Sciences, v.30, p.91-96, 1999.

BEERS, E.H.; BRUNNER, J.F.; DUNLEY, J.E.; DOERR, M.; GRANGER, K. Role of neonicotinyl insecticides in Washington apple integrated pest management. Part II. Nontarget effects on integrated mite control. Journal of Insect Science, v.5, p.1-10, 2005.

BITZER, R.J.; BUCKELEW, L.D.; PEDIGO, L.P. Effects of transgenic herbicide-resistant soybean varieties and systems on surface-active springtails (Entognatha: Collembola). Environmental Entomology, v.31, p.449-461, 2002.

BOLLAND, H.H.R.; GUTIERREZ, J.; FLECHTMANN, C.H.W. World catalogue of the spider mite family: (Acari: Tetranychidae). Leiden: Brill, 1998. 392p.

BRASIL. Secretaria de Relações Internacionais do Agronegócio. Agronegócio Brasileiro: desempenho do comércio exterior. 2.ed. Brasília: MAPA/SRIA/DPIA/CGOE, 2006. 116p.

BUCKELEW, L.D.; PEDIGO, L.P.; MERO, H.M.; OWEN, M.D.K.; TYLKA, G.L. Effects of weed management systems on canopy insects in herbicide-resistant soybeans. Journal of Economic Entomology, v.93, p.1437-1443, 2000.

CHILDERS, C.C.; ABOUT-SETTA, M.M. Yield reduction in 'Tahiti' lime from Panonychus citri feeding injury following different pesticide treatment regimes and impact on the associated predacious mites. Experimental and Applied Acarology, v.23, p.771-783, 1999.

CRIA. Centro de Referência em Informação Ambiental. Species Mapper. 2002. Available in: http://splink.cria.org.br/ mapper?criaLANG=pt. Accessed on: 25 Sept. 2006.

ELDEN, T.C. Influence of soybean lines isogenic for pubescence type on twospotted spider mite (Acarina: Tetranychidae) development and feeding damage. Journal of Entomological Science, v.32, p.296-302, 1997. 
FLECHTMANN, C.H.W. Ácaros de importância agrícola. São Paulo: Nobel, 1972. 150p.

FLECHTMANN, C.H.W. Introdução à família Tarsonemidae Kramer, 1877 (Acarina) no Estado de São Paulo. Anais da Escola Superior de Agricultura Luiz de Queiroz, Piracicaba, v.24, p.265-272, 1967.

FNP. AGRIANUAL 2008: anuário da agricultura brasileira. São Paulo: FNP Consultoria \& Agroinformativos, 2007. 504p.

GAZETA GRUPO DE COMUNICAÇÕES. Anuário brasileiro da soja: 2007. Santa Cruz do Sul: Gazeta Santa Cruz, 2007. 136p.

GERSON, U.; COHEN, E. Resurgences of spider mites (Acari: Tetranychidae) induced by synthetic pyrethroids. Experimental and Applied Acarology, v.6, p.29-46, 1989.

GROUT, T.G.; RICHARDS, G.I.; STEPHEN, P.R. Further nontarget effects of citrus pesticides on Euseius addoensis and Euseius citri (Acari: Phytoseiidae). Experimental and Applied Acarology, v.21, p.171-177, 1997.

GUEDES, J.V.C.; NAVIA, D.; LOFEGO, A.C.; DEQUECH, S.T.B. Ácaros associados à cultura da soja no Rio Grande do Sul, Brasil. Neotropical Entomology, v.36, p.288-293, 2007.

JAMES, D.G. Toxicity of imidacloprid to Galendromus occidentalis, Neoseiulus fallacis and Amblyseius andersoni (Acari: Phytoseiidae) from hops in Washington State, USA. Experimental and Applied Acarology, v.31, p.275-281, 2003.

MORJAN, W.E.; PEDIGO, L.P.; LEWIS, L.C. Fungicidal effects of glyphosate and glyphosate formulations on four species of entomopathogenic fungi. Environmental Entomology, v.31, p.1206-1212, 2002.

NAVIA, D.; FLECHTMANN, C.H.W. Rediscovery and redescription of Tetranychus gigas (Acari, Prostigmata, Tetranychidae). Zootaxa, v.547, p.1-8, 2004.
PRISCHMANN, D.A.; JAMES, D.G.; WRIGHT, L.C.; TENEYCK, R.D.; SNYDER, W.E. Effects of chlorpyrifos and sulfur on spider mites (Acari: Tetranychidae) and their natural enemies. Biological Control, v.33, p.324-334, 2005.

PRITCHARD, A.E.; BAKER, E.W. A revision of the spider mite family Tetranychidae. San Francisco: Pacific Coast Entomological Society, 1955. v.2. 472p.

RITA, A.; LAJOS, N. Changes in the numbers of the common mite (Tetranychus urticae) and the rapacious mite species (Phytoseiidae) on soybeans of different maturity groups. Acta Agronomica Ovariensis, v.43, p.49-60, 2001.

SATO, M.E.; RAGA, A.; CERÁVOLO, L.C.; SOUZA FILHO, M.F. de; ROSSI, A.C.; MORAES, G.J. de. Effect of insecticides and fungicides on the interaction between members of the mite families Phytoseiidae and Stigmaeidae on citrus. Experimental and Applied Acarology, v.25, p.809-818, 2001.

SATO, M.E.; SILVA, M. da; GONÇALVES, L.R.; SOUZA FILHO, M.F. de; RAGA, A. Toxicidade diferencial de agroquímicos a Neoseiulus californicus (McGregor) (Acari: Phytoseiidae) e Tetranychus urticae Koch (Acari: Tetranychidae) em morangueiro. Neotropical Entomology, v.31, p.449-456, 2002.

SCURSONI, J.; FORCELLA, F.; GUNSOLUS, F.; OWEN, M.; OLIVER, R.; SMEDA, R.; VIDRINE, R. Weed diversity and soybean yield with glyphosate management along a north-south transect in the United States. Weed Science, v.54, p.713-719, 2006.

TRICHILO, P.J.; WILSON, L.T. An ecosystem analysis of spider mite outbreaks: physiological stimulation or natural enemy suppression. Experimental and Applied Acarology, v.17, p.291-314, 1993.

Received on August 20, 2007 and accepted on February 29, 2008 